\title{
Expression of growth hormone-releasing hormone in human primary endometrial carcinomas
}

\author{
Ioulia Chatzistamou, Andrew V Schally ${ }^{2,3}$, Agatha Pafiti, Hippokratis Kiaris ${ }^{4}$ and Helen Koutselini ${ }^{1}$ \\ Department of Pathology and ${ }^{1}$ Department of Cytopathology, Aretaieion University Hospital, Medical School, University of Athens, Vassilisis Sofias 76 , \\ Athens 11528, Greece, ${ }^{2}$ Endocrine, Polypeptide and Cancer Institute, Veterans Affairs Medical Center and ${ }^{3}$ Section of Experimental Medicine, \\ Department of Medicine, Tulane University School of Medicine, New Orleans, Louisiana 70112, USA and ${ }^{4}$ Massachusetts General Hospital Cancer Center, \\ Harvard Medical School, Bldg 149, Charlestown, Massachusetts 02129, USA
}

(Correspondence should be addressed to H Koutselini)

\begin{abstract}
Background: Hypothalamic GH-releasing hormone (GHRH) regulates GH release from the pituitary, but an ectopic production of GHRH has been detected in various non-hypothalamic tissues, especially cancers.

Objective: To investigate whether endometrial tumors produce GHRH.

Methods: Twenty-four endometrioid, three serous papillary (SP), three mixed type endometrioid/ serous papillary adenocarcinomas and one malignant mixed Müllerian tumor (MMMT) were assessed for GHRH immunoreactivity by the polyclonal anti-rabbit antibody SV95 and for the expression of GHRH mRNA by in situ hybridization using an oligonucleotide probe.

Results: Increased GHRH immunoreactivity was detected in 15 out of 24 (63\%) of the endometrioid tumors, including two out of three $(66 \%)$ of the mixed type endometrioid/serous adenocarcinomas but not in the three SP or the MMMT tumor. Cytoplasmic staining was detected in all positive cases, while in three of them strong nuclear localization of GHRH was also revealed. In situ hybridization indicated the presence of GHRH mRNA in six cases, all characterized as positive for GHRH immunoreactivity. Conclusion: GHRH is expressed in a subset of endometrial tumors, of the endometrioid type in particular. A paracrine/autocrine role for GHRH in the development of the disease should be considered.
\end{abstract}

European Journal of Endocrinology 147 381-386

\section{Introduction}

Endometrial cancer is a widespread malignancy of the female genital tract, especially in postmenopausal women. Most cases of endometrial carcinoma are detected at early stages and therefore the clinical outcome of treatment is favorable. However, a significant number of patients with early-stage disease develop localized recurrence and distal metastases (1).

According to the World Health Organization histologic classification of endometrial carcinomas, the most common type is the endometrioid adenocarcinoma. Recent studies have associated this type of cancer with an endocrine milieu of estrogen predominance and considered them sensitive to endocrine manipulations (1), while tumors of non-endometrioid histology like serous papillary adenocarcinomas, were not responsive to endocrine manipulations (1). Genetic alterations associated with the development of the endometrioid adenocarcinomas include microsatellite instability and mutations in the K-ras, PTEN and $\beta$-catenin genes, while non-endometrioid carcinomas often harbor p53 mutations and losses in several chromosomes (2). Mixed tumors containing both endometrioid and non-endometrioid elements have also been described.

Growth hormone-releasing hormone (GHRH) is a 40-44 amino acid peptide secreted by the hypothalamus which, upon binding to specific GHRH receptors in the anterior pituitary, stimulates the synthesis and release of growth hormone (GH). In turn, GH induces the production of insulin-like growth factor-I in the liver, this is a known mitogen for various cell types (3). In addition to its neuroendocrine function in regulating the release of $\mathrm{GH}, \mathrm{GHRH}$ may play a direct paracrine/autocrine role in peripheral tissues and cancers. Thus, various normal tissues, such as placenta, ovaries, testis and lymphocytes produce biologically active GHRH (4-12). Ectopic production of GHRH has also been shown in primary tumors and/or cancer cell lines from patients with lung, prostate and pancreatic cancer, as well as gynecological malignancies (13-19). 
The evidence for a possible mitogenic role of locally produced GHRH was provided by recent studies which demonstrated that the exposure of cancer cells cultured in vitro to GHRH stimulates proliferation while the antagonists of GHRH produce an inhibition both in vitro and in vivo $(18,20-23)$. These findings suggest an autocrine/paracrine role for GHRH in human tumors.

Although various studies have been performed on the role of GHRH on cancer cell lines, information on the ectopic production of this neuropeptide hormone by primary tumors is relatively sparse. In view of the endocrine nature of the endometrioid carcinomas and the recently identified mitogenic effects of GHRH in human cancers, the aim of the present study was to investigate whether endometrial tumors of the endometrioid type express GHRH. The specimens were analyzed first for GHRH-like immunoreactivity using a rabbit polyclonal antibody for GHRH (24). Then, in order to determine if positive staining is due to the local production of GHRH or the increased accumulation of the circulating GHRH by the cancer cells, the samples were analyzed by in situ hybridization for the presence of mRNA for GHRH.

\section{Subjects and methods}

\section{Specimens}

Formalin-fixed paraffin-embedded tissues from 31 patients who had been surgically treated were collected from the Surgical Pathology archives of the Department of Pathology, Aretaieion Hospital, University of Athens, Athens. The study was approved by the Hospital Ethics and Scientific Research Committee. All patients had been treated by total extrafascial hysterectomy, bilateral salpingo-oophorectomy, and pelvic and para-aortic lymph node sampling. Patients were staged according to the International Federation of Gynecology and Obstetrics (FIGO) classification, and their tumors were graded as well (G1), moderately (G2) or poorly (G3) differentiated. Data on tumor histotype, FIGO grade, age of the patient and invasion of the myometrium are shown in Table 1. For both immunohistochemistry and in situ hybridization, $4 \mathrm{~mm}$ thick sections were used.

Table 1 The age of patients, histotype, FIGO stage, invasion of the myometrium (\%), percentage of GHRH-positive cells in immunohistochemistry (IHC) and GHRH in situ hybridization (ISH) positivity.

\begin{tabular}{|c|c|c|c|c|c|c|}
\hline \multirow[b]{2}{*}{ Case no. } & \multirow{2}{*}{$\begin{array}{l}\text { Age of patient } \\
\text { (years) }\end{array}$} & \multirow[b]{2}{*}{ Histotype } & \multirow[b]{2}{*}{ FIGO grade } & \multirow{2}{*}{$\begin{array}{c}\text { Invasion of } \\
\text { myometrium (\%) }\end{array}$} & \multicolumn{2}{|c|}{ GHRH expression } \\
\hline & & & & & GHRH IHC & ISH \\
\hline 1 & 50 & $E$ & G2 & 100 & $+++^{n}$ & + \\
\hline 2 & 53 & $\mathrm{E}$ & G2 & 80 & +++ & + \\
\hline 3 & 70 & $\mathrm{E}$ & Gl & 100 & +++ & + \\
\hline 4 & 86 & $E$ & G2 & $\mathrm{N} / \mathrm{A}$ & $+++^{n}$ & + \\
\hline 5 & 68 & $E$ & GI & $\mathrm{N} / \mathrm{A}$ & +++ & - \\
\hline 6 & 63 & $\bar{E}$ & G2 & 83 & +++ & - \\
\hline 7 & $\mathrm{~N} / \mathrm{A}$ & $E$ & $\mathrm{Gl}-\mathrm{G} 2$ & 50 & +++ & - \\
\hline 8 & 60 & $\bar{E}$ & $\mathrm{Gl}$ & 33 & +++ & + \\
\hline 9 & 62 & $E+S P$ & GI & 67 & ++ & - \\
\hline 10 & 72 & $E$ & G2 & 67 & $++^{n}$ & - \\
\hline 11 & 64 & $E$ & Gl & 67 & ++ & + \\
\hline 12 & 72 & $\mathrm{E}$ & $\mathrm{Gl}$ & 25 & ++ & - \\
\hline 13 & 54 & $\mathrm{E}+\mathrm{SP}$ & GI & 33 & ++ & - \\
\hline 14 & 64 & $\mathrm{E}$ & Gl & $33-50$ & ++ & - \\
\hline 15 & 43 & $E$ & Gl & 0 & ++ & - \\
\hline 16 & 67 & $\mathrm{E}$ & G2 & 50 & ++ & - \\
\hline 17 & 87 & $\bar{E}$ & G2 & $25-33$ & ++ & - \\
\hline 18 & 90 & МMМТ & $\mathrm{N} / \mathrm{A}$ & 100 & + & - \\
\hline 19 & 68 & SP & $\mathrm{N} / \mathrm{A}$ & $67-75$ & + & - \\
\hline 20 & 49 & $\mathrm{E}$ & G2 & 50 & + & - \\
\hline 21 & 69 & $\mathrm{E}$ & GI & 100 & + & - \\
\hline 22 & 55 & $E$ & GI & 0 & + & - \\
\hline 23 & 69 & SP & G2 & 33 & \pm & - \\
\hline 24 & 59 & $E$ & Gl & 50 & \pm & - \\
\hline 25 & 53 & $\mathrm{E}$ & $\mathrm{G} 2$ & 0 & \pm & - \\
\hline 26 & 67 & $\bar{E}$ & G2 & 83 & \pm & - \\
\hline 27 & $\mathrm{~N} / \mathrm{A}$ & $\mathrm{E}$ & $\mathrm{N} / \mathrm{A}$ & 33 & \pm & - \\
\hline 28 & 66 & SP & G3 & $\mathrm{N} / \mathrm{A}$ & - & - \\
\hline 29 & 73 & $\mathrm{E}$ & G2 & 50 & - & - \\
\hline 30 & 48 & $\mathrm{E}$ & G1 & $\mathrm{N} / \mathrm{A}$ & - & - \\
\hline 31 & 66 & $E+S P$ & G2 & $\mathrm{N} / \mathrm{A}$ & - & - \\
\hline
\end{tabular}

N/A, not available; E, endometrioid; SP, serous papillary; MMMT, mixed malignant Mullerian tumor; ${ }^{n}$, nuclear staining. 


\section{Immunohistochemistry}

Serial sections from representative paraffin-embedded blocks of 31 endometrial adenocarcinomas were collected onto poly-L-lysine-coated slides and stained for GHRH antigen. The immunohistochemical detection of GHRH was performed with the rabbit anti-GHRH polyclonal antibody SV95 (24) diluted with $1 \times$ phosphate-buffered saline (PBS) at 1:200, using the Kwik-DAB kit (ThermoShandon, Pittsburgh, PA, USA) according to the manufacturer's instructions. Specimens were evaluated for positive staining and classified according to the percentage of positive cells into the following categories: $1-10 \%( \pm), 11-30 \%(+), 31-70 \%$ $(++)$ and $71-100 \%(+++)$.

\section{In situ hybridization}

In situ hybridization for the detection of the mRNA for GHRH was performed as follows. Tissue sections were de-paraffinized twice in xylene for $5 \mathrm{~min}$ and hydrated through a standard series of ethanol to double-distilled $\mathrm{H}_{2} \mathrm{O}\left(\mathrm{ddH}_{2} \mathrm{O}\right)$. Endogenous peroxidase was inhibited with $3 \% \mathrm{H}_{2} \mathrm{O}_{2}$ for $15 \mathrm{~min}$ at room temperature and specimens were washed with $\mathrm{ddH}_{2} \mathrm{O}$ and then $1 \times$ PBS. Subsequently specimens were permeabilized with $0.5 \%$ Triton-X 100 for $5 \mathrm{~min}$ on ice, washed with $1 \times$ PBS for $10 \mathrm{~min}$ three times and incubated with $20 \mu \mathrm{g} / \mathrm{ml}$ proteinase $\mathrm{K}$ in Tris-EDTA for $30 \mathrm{~min}$ at $37^{\circ} \mathrm{C}$. Sections were then rinsed three times with $1 \times$ PBS and twice with $2 \times$ SSC (10 min each). Pre-hybridization was performed at $37^{\circ} \mathrm{C}$ for $10 \mathrm{~min}$ in a buffer containing $25 \%$ formamide, $1 \mathrm{mg} / \mathrm{ml}$ yeast tRNA, $2 \times$ SSC and 10\% dextran sulfate. For hybridization, the slides were incubated for $16 \mathrm{~h}$ at $42{ }^{\circ} \mathrm{C}$ in the pre-hybridization buffer supplemented with the digoxigenin-labeled oligonucleotide riboprobe (5'-CUCGCUCUUGGUUGCUCUCU-3 ${ }^{\prime}$ ) at $5 \mathrm{ng} / \mu \mathrm{l}$. The slides were then washed with $2 \times, 1 \times$ and $0.5 \times$ SSC for $30 \mathrm{~min}$ each, rinsed with $1 \times \mathrm{PBS}$ containing $0.1 \%$ Triton-X 100 for $5 \mathrm{~min}$ and incubated for $1 \mathrm{~h}$ at room temperature with anti-digoxigenin-peroxidase conjugate (Roche), diluted in PBS at 1:500. After washing with PBS, the slides were exposed to the DAB chromogen solution for $5 \mathrm{~min}$, washed with $\mathrm{ddH}_{2} \mathrm{O}$, counterstained with hematoxylin and mounted. All reagents were obtained from Sigma unless otherwise stated.

Negative controls consisting of the substitution of the primary antibody with $1 \times$ PBS or hybridization with a digoxigenin-labeled sense riboprobe were also included for immunohistochemistry and in situ hybridization respectively.

\section{Results}

In the present study, endometrial tumors, predominantly of the endometrioid type, were analyzed for increased GHRH-like immunoreactivity using a polyclonal antibody for GHRH, and for the expression of mRNA for GHRH by in situ hybridization. Our results showed that in 15 out of $24(63 \%)$ of the endometrioid tumors and two out of three $(66 \%)$ of the mixed type endometrioid/serous tumors, a strong GHRH-like immunoreactivity $(++,+++$ specimens $)$ was detectable by means of immunohistochemistry (Table 1 and Fig. 1). Among 17 GHRH-immunopositive specimens, six revealed the expression of GHRH mRNA by in situ hybridization, confirming that the source of the GHRH-like immunoreactivity is GHRH produced locally by the cancer cells (Fig. 2). Among these six specimens, positive for GHRH mRNA, case no. 1 had metastases in the lymph nodes and extension in the endocervix. There was no healthy endometrium in the section tested to allow for the evaluation of GHRH mRNA expression in normal tissue. Case no. 2 exhibited atypical complex hyperplasia in the non-neoplastic tissue. The remaining four cases corresponded to menopausal women, 60-72 years of age. Normal endometrium was absent from the sections available.

\section{Discussion}

We have shown that endometrial cancers are the source of ectopic production of GHRH. Among the 31 cases examined, 17 were positive for GHRH immunoreactivity. In six of these 17 GHRH-immunopositive cases, the expression of mRNA for GHRH was also detected by in situ hybridization. It must be mentioned that the term 'ectopic' may not be applicable for GHRH, as well as other hypothalamic neuropeptides, i.e. luteinizing hormone-releasing hormone, because their production in non-hypothalamic tissues may be associated with physiological functions and not necessarily only with pathological conditions. This is in agreement with a recent study by Khorram et al. (17) who demonstrated the expression of mRNA for GHRH in normal endometrial tissue. According to the same study, the levels of GHRH mRNA were significantly increased in secretory endometrium compared with proliferative endometrium (17). In the present study, only three specimens were obtained from patients younger than 50 years. Most patients, 20 out of 29 cases examined for whom age was available, were older than 60 and presumably menopausal (Table 1 ).

The failure to detect mRNA for GHRH in the remaining 11 specimens, which were positive for GHRH-like immunoreactivity, may be due to a combination of factors, such as the relatively higher half-life of the GHRH peptide in these tumors, as compared with the corresponding mRNA, as well as high local accumulation of GHRH which is produced by other sources. Thus, the sensitivity of the immunohistochemical detection of GHRH was greater compared with in situ hybridization. These findings suggest that GHRH is probably implicated in the pathogenesis of the disease by autocrine or 

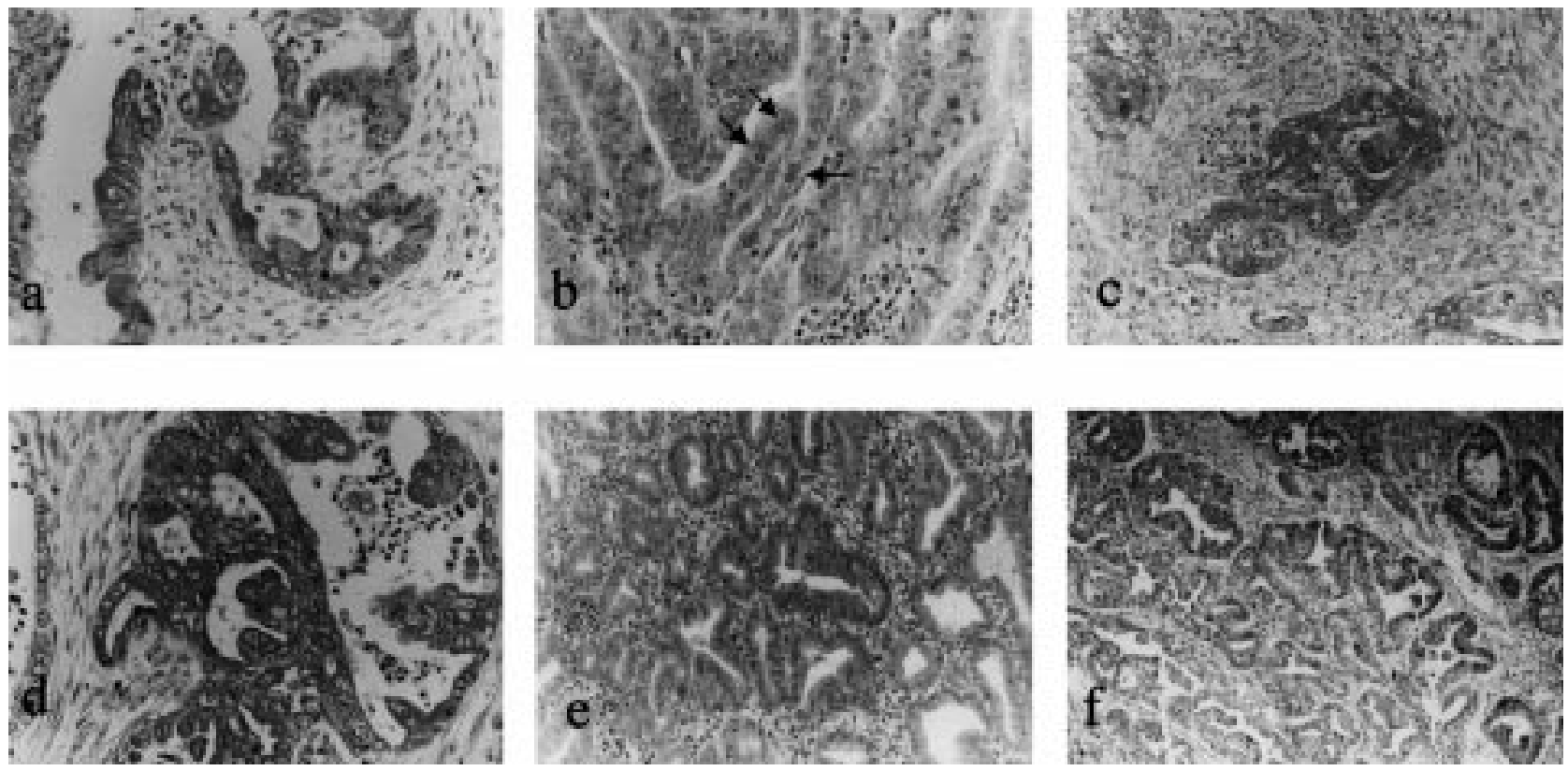

Figure 1 Immunohistochemical detection of GHRH in endometrioid adenocarcinomas of the uterus. Immunohistochemical positivity is mainly shown in the glands, while the endometrial stroma is negative for GHRH $(a-e)$. In (b), the arrows indicate nuclear staining. (f) Negative control (primary antibody has been omitted).
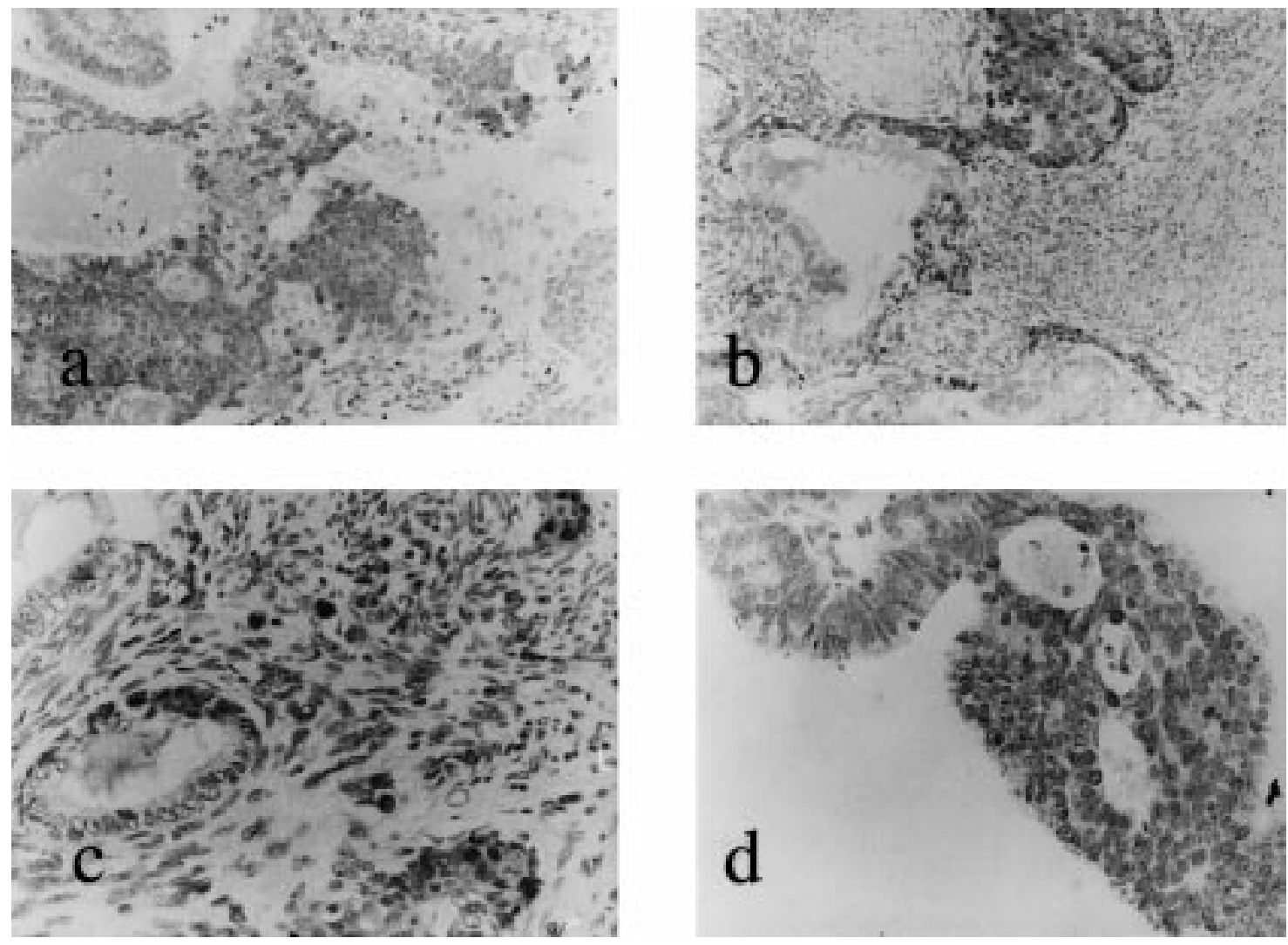

Figure 2 Detection of GHRH mRNA by in situ hybridization in endometrioid adenocarcinomas of the uterus. Nuclear positivity was sparse, featuring a clonal pattern of the expression of the mRNA for GHRH. 
paracrine mechanisms. None of the specimens which were found to be negative for GHRH-like immunoreactivity was positive in in situ hybridization, indicating that the cross-reactivity of the anti-GHRH antibody used in our study, with other GHRH-like antigens expressed by the tumors tested, cannot account for the positive staining.

The expression of GHRH was demonstrated only in the endometrioid tumors, while the three serous adenocarcinomas and the mixed Müllerian tumor included in the present evaluation were negative for GHRH-like immunoreactivity. Although the number of specimens, particularly of the serous tumors, was limited, these findings suggest that an ectopic expression of GHRH might be associated with the development of the endometrioid type of endometrial cancers only. This is consistent with the endocrine nature of the endometrioid adenocarcinoma, as compared with other types of endometrial cancers (1).

In the GHRH-immunopositive specimens, GHRH was predominantly localized in the cytoplasm, probably because of the production of GHRH by the endoplasmic reticulum in the GHRH-producing cells or because of the internalization of this neuropeptide after receptor binding, which eventually results in the degradation of GHRH. The latter possibility applies to both GHRHproducing and non-producing cells and is supported by the observation that, in 11 out of 17 immunopositive specimens, mRNA for GHRH was not detected. Furthermore, in the specimens found to be positive for both GHRH mRNA and GHRH peptide, immunohistochemistry revealed a relatively uniform pattern of staining but, in in situ hybridization, the positivity was frequently variable from one cell to another and featured a clonal pattern. This pattern points to the paracrine action of this neuropeptide on cells adjacent to the GHRH-producing cells. The cancer cells may not be the only targets for the locally produced GHRH, and an effect on the stroma of the tumor should also be considered. This is in agreement with recent findings showing that JI-38, an agonist of GHRH, can stimulate the proliferation and increase the levels of c-myc mRNA in normal human dermal fibroblasts (25). Interestingly, in three cases a strong nuclear staining was apparent in a mosaic pattern, i.e. not involving all tumoral cells. This could be due to the deregulation of the sorting machinery of the cancer cells resulting in the misplacement of GHRH in the nucleus. An additional intriguing possibility, which remains to be validated experimentally, is that GHRH in some tumors may have some action not yet identified.

The receptors that mediate the effects of GHRH on endometrial tumor cells have not been identified so far. However, it has recently been shown that primary human tumors (G Halmos, A V Schally \& R Busto, unpublished observations) and various human cancer cell lines (26-29), express splice variants of GHRH receptors which encode for alternate forms of the receptor protein. Among these splice variants, SV1 appears to be the main isoform and is the most frequently expressed (26-29). We have recently shown that 3T3 fibroblasts transfected with SV1 can respond to the mitogenic effects of GHRH analogs (30). Thus, the expression of SV1 in 3T3 induced the responses to GHRH and GHRH antagonists (30). In addition, GHRH receptor belongs to a seven-transmembrane family of receptors, which also includes the receptors for vasoactive intestinal polypeptide (VIP), pituitary adenylate cyclase-activating polypeptide, calcitonin and others (31). These receptors, especially the receptors for VIP, are known to regulate cell proliferation (32). Considerable homology exists among the aforementioned receptors, as well as their corresponding ligands; cross-reaction between GHRH and these receptors would therefore not be unexpected (31).

The present study identifies, for the first time, the endometrial tumors of the endometrioid type as a source of ectopic production of GHRH. Considering the mitogenic effects of GHRH in various tumors (4), our work could also implicate neuropeptide GHRH in the pathogenesis of this disease. The present findings also suggest that approaches to therapy of endometrial cancer based on antagonists of GHRH merit investigation.

\section{References}

1 Emons G, Fleckenstein G, Hinney B, Huschmand A \& Heyl W. Hormonal interactions in endometrial cancer. Endocrine-Related Cancer 20007 227-242.

2 Matias-Guiu X, Catasus L, Bussaglia E, Lagarda H, Garcia A, Pons C et al. Molecular pathology of endometrial hyperplasia and carcinoma. Human Pathology 200132 569-577.

3 Schally AV \& Comaru-Schally AM. Agonistic analogs of growth hormone-releasing hormone $(\mathrm{GH}-\mathrm{RH})$ : endocrine and growth studies. In Growth Hormone Secretagogues in Clinical Practice, pp 131-144. Eds BB Bercu \& RF Walker. New York: Marcel Dekker, 1998.

4 Schally AV \& Varga JL. Antagonistic analogs of growth hormonereleasing hormone: new potential antitumor agents. Trends in Endocrinology and Metabolism $199510383-391$.

5 Margioris NM, Brockmann G, Bohler HCL Jr, Grino M, Vamvakopoulos N \& Chrousos GP. Expression and localization of growth hormone-releasing hormone messenger ribonucleic acid in rat placenta: in vitro secretion and regulation of its peptide product. Endocrinology $1990 \mathbf{1 2 6} 151-158$.

6 Berry SA \& Pescovitz OH. Identification of a rat GHRH-like substance and its mRNA in rat testis. Endocrinology $1988 \mathbf{1 2 6}$ 661-663.

7 Moretti C, Fabbri A, Gnessi L, Bonifacio V, Bolotti M, Arizzi M et al. Immunohistochemical localization of growth hormone-releasing hormone in human gonads. Journal of Endocrinology 199013 301-305.

8 Stephanou A, Knight RA \& Lightman SL. Production of growth hormone-releasing hormone-like peptide and its mRNA by human lymphocytes. Neuroendocrinology 199153 628-633.

9 Ciampani T, Fabbri A, Isidori A \& Dufau ML. Growth hormonereleasing hormone is produced by rat Leydig cell in culture and acts as a positive regulator of Leydig cell function. Endocrinology $19921312785-2792$. 
10 Bagnato A, Moretti C, Ohnishi J, Frajese G \& Catt KJ. Expression of the growth hormone-releasing hormone and its peptide product in the rat ovary. Endocrinology $19921301097-1102$.

11 Gaylinn BD. Molecular and cell biology of the growth hormonereleasing hormone receptor. Growth Hormone and IGF Research $1999937-44$.

12 Moretti C, Bagnato A, Solan N, Frajese G \& Catt KJ. Receptormediated actions of growth hormone releasing factor on granulosa cell differentiation. Endocrinology 1990127 2117-2126.

13 Frohman LA \& Szabo M. Ectopic production of growth hormone releasing factor by carcinoid and pancreatic islet tumors associated with acromegaly. Progress in Clinical and Biological Research $198174259-271$.

14 Rivier J, Spiess J, Thorner M \& Vale W. Characterization of a growth hormone-releasing factor from a human pancreatic islet tumour. Nature 1982300 276-278.

15 Guillemin R, Brazeau P, Bohlen P, Esch F, Ling N \& Wehrenberg WB. Growth hormone-releasing factor from a human pancreatic tumor that caused acromegaly. Science 1982218 585-587.

16 Kahan Z, Arencibia JM, Czernus VJ, Groot K, Kineman RD, Robinson WR et al. Expression of growth hormone-releasing hormone (GH-RH) messenger ribonucleic acid and the presence of biologically active GH-RH in human breast, endometrial, and ovarian cancers. Journal of Clinical Endocrinology and Metabolism $199984582-589$.

17 Khorram O, Garthwaite M, Grosen E \& Golos T. Human uterine and ovarian expression of growth hormone-releasing hormone messenger RNA in benign and malignant gynecological conditions. Fertility and Sterility 200175 174-179.

18 Kiaris H, Schally AV, Varga JL, Groot K \& Armatis P. Growth hormone-releasing hormone: an autocrine growth factor for small cell lung carcinoma. PNAS 199996 3098-3103.

19 Chopin LK \& Herington AC. A potential autocrine pathway for growth hormone releasing hormone (GHRH) and its receptor in human prostate cancer cell lines. Prostate 200149 116-121.

20 Csernus VJ, Schally AV, Kiaris H \& Armatis P. Inhibition of growth, production of insulin-like growth factor-II (IGF-II), and expression of IGF-II mRNA of human cancer cell lines by antagonistic analogs of growth hormone-releasing hormone in vitro. PNAS 199996 3098-3103.

21 Chatzistamou I, Schally AV, Varga JL, Groot K, Armatis P, Busto R et al. Antagonists of growth hormone-releasing hormone and somatostatin analog RC-160 inhibit growth of OV-1063 human epithelial ovarian ca. cell line xenografted into nude mice. Journal of Clinical Endocrinology and Metabolism 200186 2144-2152.

22 Chatzistamou I, Schally AV, Varga JL, Groot K, Busto R, Armatis P et al. Inhibition of growth and metastases of MDA-MB-435 human estrogen-independent breast cancers by an antagonist of growth hormone-releasing hormone. Anticancer Drugs 200112 $761-768$.

23 Szepeshazi K, Schally AV, Armatis P, Groot K, Hebert F, Feil A et al. Antagonists of GHRH decrease production of GH and IGF-I in MXT mouse mammary cancers and inhibit tumor growth. Endocrinology $20011424371-4378$.

24 Groot K, Csernus VJ, Pinski J, Zsigo J, Rekasi Z, Zarandi M et al. Development of a radioimmunoassay for some agonists of growth hormone-releasing hormone. International Journal of Peptide and Protein Research 199341 162-168.

25 Kiaris H, Schally AV \& Armatis P. Direct action of growth hormone-releasing hormone agonst JI-38 on normal human diploid fibroblasts: evidence from studies on cell proliferation and c-myc oncogene expression. Regulatory Peptides 200196 119-124.

26 Rekasi Z, Czompoly T, Schally AV \& Halmos G. Isolation and sequencing of cDNAs for splice variants of growth hormonereleasing hormone receptors from human cancers. PNAS 2000 97 10561-10566.

27 Halmos G, Schally AV, Varga JL, Plonowski A, Rekasi Z \& Czompoly T. Human renal cell carcinoma expresses distinct binding sites for growth hormone-releasing hormone. PNAS 200097 1055510560 .

28 Plonowski A, Schally AV, Busto R, Krupa M, Varga JL \& Halmos G. Expression of growth hormone-releasing hormone (GHRH) and splice variants of GHRH receptors in human experimental prostate cancers. Peptides 23 1127-1133.

29 Busto R, Schally AV, Braczkowski R, Plonowski A, Krupa M, Groot $\mathrm{K}$ et al. Expression of mRNA for growth hormone-releasing hormone (GHRH), and splice variants of GHRH receptors in human osteosarcomas. European Journal of Cancer (In Press).

30 Kiaris H, Schally AV, Busto R, Halmos G, Artavanis-Tsakonas S \& Varga JL. Expression of splice variant for GHRH receptor SV1 mediates mitogenic effects in 3T3 fibroblasts. PNAS 200299 196-200.

31 Sherwood NM, Krueckl SL \& McRory JE. The origin and function of the pituitary adenylate cyclase-activating polypeptide (PACAP)/ glucagon superfamily. Endocrine Reviews 200021 619-670.

32 Maruno K, Absood A \& Said SI. Vasoactive intestinal peptide inhibits human small-cell lung cancer proliferation in vitro and in vivo. PNAS 199895 14373-14378.

Received 18 February 2002

Accepted 16 May 2002 